\title{
EIPR1 wt Allele
}

National Cancer Institute

\section{Source}

National Cancer Institute. EIPR1 wt Allele. NCI Thesaurus. Code C49430.

Human EIPR1 wild-type allele is located in the vicinity of 2p25.3 and is approximately 189 $\mathrm{kb}$ in length. This allele, which encodes protein TSSC1, plays a role in the organization of chromatin. 